Meta

Journal des traducteurs

Translators' Journal

\title{
Training in the Application of Translation Strategies for Undergraduate Scientific Translation Students
}

\section{Maria González Davies, Christopher Scott-Tennent et Fernanda Rodríguez Torras}

Volume 46, numéro 4, décembre 2001

URI : https://id.erudit.org/iderudit/002490ar

DOI : https://doi.org/10.7202/002490ar

Aller au sommaire du numéro

Éditeur(s)

Les Presses de l'Université de Montréal

ISSN

0026-0452 (imprimé)

1492-1421 (numérique)

Découvrir la revue

Citer cette note

Davies, M., Scott-Tennent, C. \& Rodríguez Torras, F. (2001). Training in the Application of Translation Strategies for Undergraduate Scientific Translation Students. Meta, 46(4), 737-744. https://doi.org/10.7202/002490ar

\section{Résumé de l'article}

Un projet1 de recherche a été récemment effectué. Celui-ci comprenait les phases suivantes : 1 . Mettre en relief ce qui était connu d'avance ou établi comme hypothèse sur le rôle des stratégies dans le processus de traduction à travers la révision de la bibliographie pertinente. 2. Établir une définition en vigueur des stratégies de traduction. 3. Choisir trois types de problèmes pour offrir un exercice pilote où il est nécessaire d'appliquer des stratégies pour résoudre ceux-ci. 4. Mettre au point un cours théorique optimal, en tenant compte de la bibliographie pédagogique en vigueur, pour fournir un exercice d'entraînement préalable dans l'application de ces stratégies. 5. Effectuer une étude empirique pour observer, mesurer et analyser les effets d'un cours de ce genre. On peut trouver un rapport complet sur cette étude dans Investigating Translation [Recherche sur la traduction] (John Benjamins, 1999). En conclusion à cette étude, on a remarqué que le cours pilote a été considéré satisfaisant par tous les participants. De plus, il a permis aux stagiaires d'augmenter leur fréquence et effectivité dans l'application des stratégies cible. On a aussi mis en relief le fait que cela a amélioré significativement la qualité des textes cible, d'accord avec des noteurs externes. Conséquemment, le professeur de ce cours expérimental a spontanément continué à inclure ce type d'exercice dans son travail régulier. D'autres collègues ont aussi effectué des expériences similaires et en ont exprimé leur évaluation positive. L'objectif de cet article est d'établir un rapport plus exhaustif sur la méthodologie qui a été suivie dans ce cours pilote. Cela peut fournir un point de départ pratique pour le dialogue aux professeurs qui veulent mettre à l'essai ce type d'exercice dans leurs classes.
Ce document est protégé par la loi sur le droit d'auteur. L'utilisation des services d’Érudit (y compris la reproduction) est assujettie à sa politique d'utilisation que vous pouvez consulter en ligne.

https://apropos.erudit.org/fr/usagers/politique-dutilisation/ 


\section{BLOC-NOTES}

\section{Training in the Application of Translation Strategies for Undergraduate Scientific Translation Students}

\section{RÉSUMÉ}

Un projet' de recherche a été récemment effectué. Celui-ci comprenait les phases suivantes:

1. Mettre en relief ce qui était connu d'avance ou établi comme hypothèse sur le rôle des stratégies dans le processus de traduction à travers la révision de la bibliographie pertinente.

2. Établir une définition en vigueur des stratégies de traduction.

3. Choisir trois types de problèmes pour offrir un exercice pilote où il est nécessaire d'appliquer des stratégies pour résoudre ceux-ci.

4. Mettre au point un cours théorique optimal, en tenant compte de la bibliographie pédagogique en vigueur, pour fournir un exercice d'entraînement préalable dans l'application de ces stratégies.

5. Effectuer une étude empirique pour observer, mesurer et analyser les effets d'un cours de ce genre. On peut trouver un rapport complet sur cette étude dans Investigating Translation [Recherche sur la traduction] (John Benjamins, 1999).

En conclusion à cette étude, on a remarqué que le cours pilote a été considéré satisfaisant par tous les participants. De plus, il a permis aux stagiaires d'augmenter leur fréquence et effectivité dans l'application des stratégies cible. On a aussi mis en relief le fait que cela a amélioré significativement la qualité des textes cible, d'accord avec des noteurs externes.

Conséquemment, le professeur de ce cours expérimental a spontanément continué à inclure ce type d'exercice dans son travail régulier. D'autres collègues ont aussi effectué des expériences similaires et en ont exprimé leur évaluation positive. L'objectif de cet article est d'établir un rapport plus exhaustif sur la méthodologie qui a été suivie dans ce cours pilote. Cela peut fournir un point de départ pratique pour le dialogue aux professeurs qui veulent mettre à l'essai ce type d'exercice dans leurs classes.

\section{ABSTRACT}

A research project ${ }^{2}$ was recently carried out consisting of the following stages:

1. Finding out what was previously known or hypothesised about the role of strategies in the translation process by reviewing the relevant literature.

2. Deciding on an operative definition of translation strategies.

3. Selecting 3 types of problems to give experi- mental training in the application of strategies to solve them.

4. Designing a theoretically optimal course, by considering relevant pedagogical literature, to give pre-service training in the application of these strategies.

5. Carrying out an empirical study to observe, measure and analyse the effects of such a course. A full report on this study is to be found in Investigating Translation (John Benjamins, 1999).

On conclusion of the study, it was found that the experimental course had been perceived as satisfactory by all the participants, and clearly increased the frequency and effectiveness of trainees' application of target strategies. It was also found that this had significantly improved the quality of target texts, according to external raters. Subsequently, the teacher of this experimental course has spontaneously continued to include this type of training in her regular work. Other colleagues have also undertaken similar experiences and expressed their positive evaluation of them. The aim of this present article is to report more fully on the methodology which was followed in the experimental course. This could provide a useful starting point for discussion for those teachers who would like to experiment with this type of training in their own classes.

\section{MOTS-CLÉS/KEYWORDS}

translation strategies, translation training, translation problems, experimental course

\section{General course design: translation training and class dynamics}

A pilot study on the teachability of translation strategies was carried out with two groups of 12 students in their third year of undergraduate translation studies at the Facultat de Ciències Humanes, Traducció i Documentació at the Universitat de Vic (Spain). These students were taking the course "Specialized Translation: Life Sciences" (60 contact hours) and had not received any previous explicit training in translation strategies. The pedagogical design revolved around two main axes: the explicit teaching of translation strategies and the teaching of scientific translation (EnglishSpanish).

The specific strategy training they received focused on the following three translation problems (Baker 1992):

1. No lexical correspondence at word level between the source text and the target text

2. No lexical correspondence above word level: collocations, idioms and fixed expressions 
3. Textual equivalence: coping with cohesion and coherence

All the translation problems which came up during the course were discussed, but only these three were dealt with in detail. Different solutions were accepted for the same problematic segment if they were considered to be adequate after peer and peer/teacher discussion and, if necessary, consultation with a field specialist. ${ }^{3}$

The pedagogical framework integrated three approaches to translation training: (a) productbased, referring to WHAT the students achieve, i.e., what kind of translation they finally write, (b) process-based, with discussions about HOW the students achieve translation skills, i.e., a conscious reflection on what happens while the text is being produced, (c) function-based by creating an awareness of WHY, WHERE and WHEN their translation assignment is carried out, i.e., the function of each text was determined before it was translated and, moreover, a specific audience to whom the translation was addressed was agreed upon before carrying out the translation.

\section{Class dynamics: methodological principles and activity types}

In explicit teaching the syllabus is designed so that activities and explanations which focus on a chosen issue, in this case, given translation strategies, are included in it clearly and frequently. After the first presentation session on translation problems and strategies, each group of translation problems was presented every 4 weeks in introductory sessions which included three parts: a/ a presentation by the teacher, b/ discussion by the students and $c /$ a final brainstorming characterised by intense interaction between teacher-students and studentsstudents.

The classes were student-centred with the students as active protagonists of the learning act. A naturalistic approach was adopted regarding the teaching methodology and an experimental approach was adopted to analyse its results. Individual work was present in the regular 200 word translations to be handed in and in three longer translations (1,000 words) they had partially worked on previously in the classroom. Peer work was usually carried out following a pyramidal structure, that is, the individual work done in the classroom or at home was compared with that of a fellow student and finally pooled in a group of 3 or 4 students.

Activities were both pedagogic and real life (Nunan 1989) and included written and oral translation, team translation to discuss and unify adequacy, style, terminology, etc., editing each other's translations, sharing knowledge about resourcing facilities and discussing translation in general and their texts in particular.

In this context the teacher's role was to provide adequate strategies for learning and act as a guide or counsellor, not as a problem-solver. Cooperative learning and a continuous encouragement of learner autonomy formed part of the process.

Authentic materials, that is, teaching material which has not been manipulated for pedagogical purposes, were included in an anthology structured around text-types and topics in scientific translation with a special, but not exclusive, emphasis on medical texts.

These pedagogical and translation principles were designed to build bridges between the classroom and the professional world: both individual and team work were favoured, resourcing was predominant, and different texts were translated with potential clients in mind.

\section{Course description and activities}

What follows is a more detailed description of the steps followed at each key stage to give explicit training in strategy use. A selection of activities which illustrated the pedagogic principles mentioned above is also included. In all cases, problem-spotting and solving were highlighted but the whole texts were translated to keep the translation training setting as natural as possible.

As regards assessment, the students were evaluated in different ways, both numerically and holistically, by the teacher, by their peers and by field specialists. The teacher applied the numerical marking system used in her Department, which is based on Hatim and Mason (1990) and Hurtado (1994), thus fitting this teaching style comfortably into the assessment policy that was being followed previously, and devised a holistic system which would take the student closer to the real translation market. Thus, if the students received a grade such as "6 / ATI" (see below), they understood that, although they had passed from a pedagogical perspective, their translation would have to be changed substantially before it could be accepted by a potential client.

\section{Numerical marking system}

\begin{tabular}{|l|l|}
\hline PROBLEM & $\begin{array}{l}\text { MARKS (general guidelines } \\
\text { depending on the kind of } \\
\text { error or on positive solutions. } \\
\text { Total: } 10 \text { ) }\end{array}$ \\
$\begin{array}{l}\text { Source Message: not } \\
\text { transmitted }\end{array}$ & $\begin{array}{l}\text { minus } 1 \text { or } 2 \\
\text { minus } 0.25 \text { or } 0.5 \\
\text { Incomplete without } \\
\text { hindering message }\end{array}$
\end{tabular}




\begin{tabular}{|l|l|}
\hline $\begin{array}{l}\text { Source Text } \\
\text { Comprehension: register, } \\
\text { coherence, cohesion, } \\
\text { syntax, vocabulary, } \\
\text { word order, etc. }\end{array}$ & 2 or 3 errors = minus 1 \\
\hline $\begin{array}{l}\text { Transfer skills: Suitable } \\
\text { application of translation } \\
\text { strategies - if required } \\
\text { (strategies were taken } \\
\text { as a means, not as an } \\
\text { end, so students who } \\
\text { arrived at a good } \\
\text { solution without using } \\
\text { the studied strategies } \\
\text { were not penalized) }\end{array}$ & $\begin{array}{l}\text { puitable solution }= \\
\text { unsuitable solution }=\end{array}$ \\
\hline $\begin{array}{l}\text { Target Text Legibility: } 1 \\
\text { register, coherence, } \\
\text { cohesion, syntax, } \\
\text { vocabulary, word order, } \\
\text { cultural references, etc. }\end{array}$ & 2 or 3 errors = minus 1 \\
\hline $\begin{array}{l}\text { General impression } \\
\text { (if necessary) }\end{array}$ & plus 1, no change, \\
\hline
\end{tabular}

\section{Holistic marking system}

a. This translation transmits the source message, conforms to the target language conventions, and keeps to the assignment. It would be accepted with few or no changes: Acceptable translation - AT

b. This translation contains errors which could hinder the understanding of the text or which do not transmit part of the source message adequately - Acceptable translation, but must be improved - ATI

c. This translation contains several errors which imply a lack of comprehension of the source text. Problematic legibility of the target text. No evidence of problem spotting and solving, either with or without the help of strategies - Unacceptable translation - UT

\section{Highlighting the usefulness of translation strategies}

\section{Aims and teaching approach}

a. Awareness raising of translation problems and possible solutions

b. Familiarisation with the notion of strategy as a conscious non-automatic solution to a translation problem ${ }^{4}$

c. Introduction to the written protocols

\section{Procedure}

a. The teacher asked for the translation of words and expressions which are semantically narrow, e.g., dog, the cat is on the mat, table, this is a tree, etc. The students were asked to translate simultaneously.

b. The students were asked whether these would present any translation problems if they were in different contexts. They answered that the contexts would have to be very specific to present any problems.

c. The same procedure was followed with more open words and expressions such as cup, of course, hold on, etc. In this case, the students immediately asked about the context for each of these and gave different translations according to each one.

d. A discussion followed about questions such as: what goes on in our mind when we translate? How do we spot a translation problem? How do we solve it?

e. The concept of strategy was introduced as well as the chosen definition.

f. The students translated a text on fibre optic networks in groups of 3 or 4 . They were asked to read it, list the problems and pool their solutions. In order to do this, they received a written protocol designed for them to record their solutions to the translation problems found in this and subsequent texts (see fig. 1). The students had to hand in a written protocol with each of the translations they carried out outside the classroom. Each sheet consisted of three columns: in the first, they had to write down the problem found in the source text, in the second, the name of the strategy they used to solve it, and in the third, their solution.

Examples of problems/strategies/solutions proposed by the learners for this text

\begin{tabular}{|l|l|l|}
\hline PROBLEM & STRATEGIES & SOLUTIONS \\
\hline intellitainments & $\begin{array}{l}\text { make up a } \\
\text { new word }\end{array}$ & intelimiento \\
\hline $\begin{array}{l}\text { Information } \\
\text { Superhighway }\end{array}$ & $\begin{array}{l}\text { ask a field } \\
\text { specialist }\end{array}$ & infopistas \\
\hline
\end{tabular}

\section{Students' reactions ${ }^{5}$}

Generally speaking, they seemed to have grasped the idea, but had trouble differentiating the notions of problem and strategy. They spotted the problems and applied solutions, although they could not explain what was going on in their minds. 
Introducing translation strategies group 1 (TSG1).

Problem: no lexical correspondence at word level

\section{Aims and teaching approach}

a. Discussion about translation strategies

b. Introduction to the strategies presented in Baker (1992) (see below)

\section{Procedure}

a. The students compared their translations and written protocols in new groups formed by members from the previous groups.

b. The teacher wrote No lexical correspondence on the blackboard and asked the students to write down different strategies which can be applied when this happens. They could look at their translations, written protocols and notes.

c. Each group produced a list of strategies.

d. Baker's were presented, discussed and added to the students' list (see below).

e. The students handed in their translations and written protocols.

\section{Strategies presented to solve non-equivalence at word level}

Problems

a. Culture-specific concepts

b. The source language concept is not lexicalized in the target language

c. The source language word is semantically complex

d. The source and target languages make different distinctions in meaning

e. The target language lacks a superordinate

f. The target language lacks a specific term (hyponym)

g. Differences in physical or interpersonal perspective

h. Differences in expressive meaning

i. Differences in form

j. Differences in frequency and purpose of using specific forms

$k$. The use of loan words in the source text
The students' additions to the previous list

\author{
a. explicitation \\ b. transliteration \\ c. footnote \\ d. loan word \\ e. glossary at end of book
}

\section{Students' reactions}

When dealing with point (b), there seemed to be a division between those who could not see the point, a little over half the group, and those who were enthusiastic with the idea. This, of course, may be directly related to learner styles. When moving on to points (c) and (d), though, a majority expressed a positive attitude.

\section{Applying TSG1: aims and teaching approach}

a. Discussion about the importance of translation assignment

b. Practice of technical writing skills: semispecialised language and synthetic translation

c. Peer assessment

\section{Procedure}

a. The teacher gave back to the students their translations and a discussion and review of the list of strategies followed.

b. A worksheet prepared on the documentary Orangutan (National Geographic) was handed out and the instructions followed.

\section{Students' reactions}

When carrying out the activities in the worksheet a few asked what they should do if they could not find a solution. The teacher, with the participation of other students, answered that the main aim of teaching strategies explicitly was to systematise them according to their own experience-and that of theorists and professional translators - so that the lists they were drawing up were meaningful and could be used always. In this way, the like/do not like criteria could be improved and suitable translation solutions need not depend exclusively on "inspiration".

Introducing translation strategies group 2 (TSG2).

Problem: non-correspondence above word level: collocations, idioms and fixed expressions

Aims and teaching approach

a. Discussion of translation strategies

b. Introduction to the strategies presented in Baker (1992) 
c. Translation depending on a potential client's assignment

d. Discussion on readers' expectations as related to translators' expectations before reading a text

e. Practice of writing skills in the target language: technical writing vs. non-technical translation of the same text

f. Peer editing

g. Team translation

h. Task-based learning

\section{Procedure}

a. The teacher wrote No lexical correspondence above word level: collocations, idioms and fixed expressions on the blackboard. The students had about ten minutes to look at their translations, written protocols and notes and write down different strategies which can be applied when this happens.

b. Each group produced a list of strategies.

c. Baker's were presented, discussed and added to the students' list (see below).

d. The chosen text was Nightmare of the Monster Cities. The students were sensitised to the topic through discussing open questions on the cities of the future, life in the next Millennium, the effects of globalisation, etc.

e. The students read the text individually and underlined collocations, idioms and fixed expressions. A class brainstorming followed.

f. Each group of 3 or 4 students was asked to translate the same text for different clients: half the text was for a well-known Spanish semi-specialised journal and the other half was for a non-specialised journal. The group could choose which part would match the different assignments.

g. Before starting, the guidelines for contributors of each journal were handed out and discussed.

h. The translations were carried out using the list of TSG2. The list of TSG1 could also be used if necessary. A written protocol was filled in indicating 4 problems, strategies and solutions belonging to TSG2 for each assignment.

i. Each group then handed over its translations and written protocols to another group who first had to spot which part corresponded to each of the assignments and then proceeded to edit the translations and comment on the written protocols.

j. Both groups (the "editors" and the "edited") sat together and discussed their texts.

Strategies presented to solve non-equivalence above word level: collocations, idioms and fixed expressions

Problems

Some strategies used by professional translators

(Baker 1992: 46-77)

a. COLLOCATIONS

- The engrossing effect of source text patterning can lead, e.g., to involuntary calques

- Misinterpreting the meaning of source language collocation

- The tension between accuracy and naturalness

- Culture-specific collocations

- Marked collocations in the source text

b. IDIOMS AND FIXED EXPRESSIONS

- Recognition

- No equivalent in the target language

- A similar counterpart in the target language with a different context of use

- An idiom used in the source text both in its literal and idiomatic sense at the same time

- Difference between the convention, context and frequency of use in the source and target languages a. COLLOCATIONS

- be alerted to the potential influence of the source text

- put the translation draft aside for a few hours and return to read the target text so that the possible interfering influence of source text patterning is reduced

- evaluate the significance of a potentia change in meaning

- Translation by a marked collocation depending on the constraints of the target language and the purpose of the translation

b. IDIOMS AND FIXED EXPRESSIONS

- Resourcing

- Using an idiom of similar meaning and form

- Using an idiom of similar meaning but differing form

- Paraphrase

- Omission

- Compensation

- Rewording

- Translation by paraphrase using unrelated words

- Translation by illustration

The students' additions and comments to the previous list

a. Total correspondence

- Find an exact equivalent in meaning, lexis and grammatical structure

b. Partial correspondence

- Find a correspondence in meaning or form (lexis or structure)

- Coin a new phrase keeping the traditional characteristics of these expressions: lexis, structure and, especially, internal rhyme 
c. Non-correspondence

- Compensation, especially for long texts

- Omission was not felt to be "professional"

- Footnotes, especially for word play

- Leave ("') in the target text and either paraphrase or translate literally in a footnote or use explicitation

\section{Students' reactions}

The students were extremely interested in this group of problems and in finding ways to solve them. The application of the strategies generated an intense discussion with much student/student interaction and the teacher acting as moderator. Most students wanted to use the list of TSG1 as well as TSG2 and commented that they were beginning to feel more self-confident when dealing with translation problems because they felt they were moving away from lucky guesses and learning to think about their own work. However, they were still worried about adequacy, that is, choosing the most suitable solution for a problem.

\section{Introducing translation strategies group 3 (TSG3).}

Problem: textual equivalence: coping with cohesion and coherence

\section{Aims and teaching approach}

a. Discussion about translation strategies

b. Introduction to the strategies presented in Baker (1992)

c. Assessment of a professional translation of part of the chosen text and comparison with that of the students' themselves.

d. Assessment by different markers: peers, teacher and field expert.

\section{Procedure}

a. The teacher wrote: Textual equivalence: cohesion and coherence on the blackboard. A discussion on the meaning and the implications for translation of each of these terms followed.

b. The students wrote a list of instances of cohesion: number, gender, person, time, etc. and of coherence: genre, text type, etc. and pooled them.

c. The strategies presented by Baker were complemented with others proposed by the students. The list was left open so that more could be added after working with the text Joy of Analog (Time 26.5.1986).

d. The students were asked to read the whole text and underline any problems they could find related to TSG3. A brainstorming session followed.

e. The students were asked to translate part of the text and to fill in the written protocols individually. f. In groups of 3 or 4 students a translation carried out by a professional translator was assessed both as a final product and considering the strategies of any group spotted.

g. New groups were formed with members belonging to each of the previous groups to discuss their conclusions.

h. Finally, the students went back to their original groups, reported what had been said and assessed a fellow student's translation of the same piece.

i. In the class discussion that followed, more problems, strategies and solutions were added to the list.

j. The students' translations were assessed by a professional journalist specialised in scientific topics who had not read the source text and, thus, could not be influenced by it. The assessment was based on target language conventions and readability. Each student received feedback from this marker and discussed it individually with the teacher.

\section{Strategies presented to solve textual equivalence: cohesion and coherence}

\section{Problems}

Some strategies used by professional translators (Baker 1992: 119-215)

$\begin{array}{ll}\text { gender } & \text { adding } \\ \text { person } & \text { deleting } \\ \text { verb tense } & \text { reordering } \\ \text { restrictions of word order } & \begin{array}{l}\text { producing different lexical } \\ \text { chains } \\ \text { explicitation }\end{array}\end{array}$
according to word order deictics

rechunking (reorganizing or renumbering paragraphs, sentences) text type repunctuating

genre

The students' additions and comments to the previous

a. Read:

- aloud

- to somebody else

- by somebody else

- focus on intonation

- gap-filling test for another reader to discuss different translation options

b. Chunk (discover the internal structure of a text with the help of wh- questions)

c. Change of word order ("puzzle" with words and clauses until they "fit")

d. Analyse target language parallel texts on the same subject and corresponding to the same text type

- be aware of target language legibility and text conventions 


\section{Students' reactions}

The students remembered the strategies of all three groups (TSG1, TSG2, TSG3) and applied and named them with ease. They felt more confident about adding strategies to Baker's list and about commenting on those that appeared. They seemed to work much longer individually and did not need as much group work as before. Also, fewer questions were addressed to the teacher. The biggest change in attitude was that they relaxed and admitted different solutions for the same problem as long as they could see a reason behind the choice: different translator and strategy-choice styles were accepted.

\section{Final report}

Our approach was both naturalistic and empirical. It can be said that specific strategy training created a learning experience clearly perceived as satisfactory by all the participants, according to the teacher's class diary and the students' course evaluation.

The two basic means which favoured a positive attitude were group and class discussions, and the written protocols which enabled the students to visualise their progress. After the first three weeks, the students were able to say why they had chosen an item and given this choice a name. By the end of the course, they were approaching their texts with more confidence, they were beginning to systematise their disperse knowledge and they were producing more coherent translations.

On the last day, they were asked to write down their impressions about having dealt with translation strategies explicitly. When asked whether they were in favour or against learning about translation strategies, no one answered against, 12 answered in favour and 2 were partially against explicit teaching and learning. All the following are transcriptions of the students' actual words: useful for all translation subjects, useful to discuss translation with client and positive for professional future, favour self-confidence when making changes in a text, help to justify changes, make translating easier and more agile, systematisation is positive, help raise quality in translations, help the unconscious to surface, help to reflect on the translation process. Reasons against: too theoretical, are immediately forgotten, difficult to grasp at the beginning, "torture" (tormento) until you understand what it is all about, not logical enough for my methodology, more useful when you become used to the names.

From the teacher's point of view, the outcome was also positive: the students' efforts could be appreciated fully, their progress could be seen graphically and their problems solved straightaway, the individual learning stages could be fol- lowed, and there was greater respect for the students' translations, i.e., their translator styles and their strategy-use styles, because they were expressing their choices in a clear way.

Consciousness raising can be more effective when the learners not only apply the target principles, but take active part in this application themselves - thus, they can-and, in fact, didadd self-discovered strategies to existing lists. This, hopefully, will continue in their professional lives.

Maria González Davies Christopher Scott-Tennent Fernanda Rodríguez Torras University of Rovira $i$ Virgili, Tarragona, Spain

\section{NOTES}

1. Recherche financée par la Universitat Rovira $i$ Virgili (Tarragone, Espagne). Subvention: Ajuts a la recerca $9678 \mathrm{C}$.

2. Research funded by the Universitat Rovira $i$ Virgili (Tarragona, Spain). Grant: Ajuts a la recerca $9678 \mathrm{C}$.

3. For an extensive account of the active participation of field specialists in the assessment of the students' translations see González Davies, M., 1998.

4. Our full operative definition is that the application of a translation strategy depends on the steps, selected from a consciously known range of potential procedures, taken to solve a translation problem which has been consciously detected and resulting in a consciously applied solution.

5. All students' reactions are taken from the teacher's class diary

6. Baker (1992: 21) clarifies that no one-to-one correspondence should be established between problems and strategies and we would agree.

\section{REFERENCES AND FURTHER READING}

BAKer, M. (1992): In Other Words, London \& New York: Routledge.

Dollerup, C. and A. LodegaArd, eds. (1993): Teaching Translation and Interpreting 2, Amsterdam \& Philadelphia: Benjamins.

Dollerup, C. and V. Appel, eds. (1996): Teaching Translation and Interpreting 3, Amsterdam \& Philadelphia: Benjamins.

Duff, A. (1989): Translation, Oxford: Oxford University Press.

GiLe, D. (1995): Basic Concepts and Models for Interpreter and Translator Training, Amsterdam \& Philadelphia: Benjamins.

GonzÁlez Davies, M. (1998): "Student Assessment by Medical Specialists: An Experiment in Relating the Undergraduate to the Professional World in the Teaching of Medical Translation in Spain", In Fischbach, H. (ed), Translation and Medicine, ATA (American Translators 
Association) Scholarly Monographic Series, Vol. X. Amsterdam: John Benjamins.

Hatim, B. and I. Mason (1990): Discourse and the Translator, London and New York: Longman.

Henvey, S., Higgins, S. and L. Haywood (1995): Thinking Spanish Translation: A Course in Translation Method, London \& New York: Routledge.

Hurtado, A. (1994): "Didáctica de la Traducción", In Le Bel, E. (ed), Traducción: reflexiones, experiencias y prácticas. Sevilla: Publicaciones Universidad de Sevilla.

Kiraly, D. (1995): Pathways to Translation. Pedagogy and Process, Kent \& London: The Kent State University Press.

Kussmaul, P. (1995): Training the Translator, Amsterdam \& Philadelphia: Benjamins.

Lörscher, W. (1992): "Process-oriented research into translation and its implications for translation teaching", Interface: Journal of Applied Linguistics 6,2. 105-117.

Nord, C. (1997): Translating as a Purposeful Activity, Manchester: St. Jerome.

Nunan, D. (1989): Designing Tasks for the Communicative Classroom, Cambridge: Cambridge University Press. 